\title{
Faktor Prediktor Nefritis pada Anak dengan Purpura Henoch-Schonlein
}

\author{
Ahmad Wisnu Wardhana, Cahya Dewi Satria, Sunartini \\ Bagian Ilmu Kesehatan Anak Fakultas Kedokteran Universitas Gadjah Mada/RSUP Dr. Sardjito, Yogyakarta
}

Latar belakang. Penyakit purpura Henoch-Schonlein (PHS) dapat menyebabkan komplikasi nefritis. Nefritis PHS dapat membaik sendiri atau berkembang menjadi penyakit ginjal kronik. Beberapa faktor prediktor telah diketahui berhubungan dengan kejadian nefritis PHS.

Tujuan. Menentukan usia $\geq 10$ tahun, purpura persisten, gejala abdomen berat dan relaps sebagai faktor prediktor nefritis pada PHS. Metode. Dilakukan studi kohort retrospektif. Sampel penelitian adalah anak berusia 1 tahun - 18 tahun dengan PHS yang dirawat di Instalasi Kesehatan Anak RSUP Dr. Sardjito Yogyakarta periode Januari 2008-Agustus 2016 yang memenuhi kriteria inklusi. Sampel diambil secara konsekutif, kemudian diidentifikasi adanya faktor prediktor nefritis berdasarkan data rekam medis. Analisis bivariat untuk menghitung nilai p serta analisis multivariat dengan regresi logistik.

Hasil. Diikutsertakan 80 pasien yang yang diikuti selama 6 bulan. Didapatkan nefritis pada 31 pasien (38,75\%). Analisis bivariat dan multivariat menunjukkan bahwa hanya gejala abdomen berat yang merupakan faktor prediktor nefritis dengan nilai $\mathrm{p}=0,027$ dan $\mathrm{p}=0,021$, dan RR 3,759 (IK95\%: 1,222-11,562).

Kesimpulan. Gejala abdomen berat merupakan faktor prediktor pada kejadian nefritis PHS dan meningkatkan risiko 3,75 kali terjadinya nefritis PHS. Usia $\geq 10$ tahun, purpura persisten, dan relaps tidak terbukti berpengaruh pada kejadian nefritis PHS. Sari Pediatri 2016;18(3):209-13

Kata kunci: purpura Henoch-Schonlein, faktor prediktor, nefritis, gejala abdomen berat, purpura persiste

\section{Nephritis Predictive Factors in Children with Henoch-Schonlein Purpura}

\author{
Ahmad Wisnu Wardhana, Cahya Dewi Satria, Sunartini
}

Background. Nephritis could be a complication of Henoch-Schonlein purpura (HSP). Henoch-schonlein purpura nephritis (HSPN) could be self limited or develop to chronic kidney disease. Some predictive factor for nephritis Henoch-Schonlein purpura has been identified .

Objective. To determine age $\geq 10$ years, persistent purpura, severe abdominal symptom and relaps are predictive factors for HSPN. Methods. A retrospective study was performed. Samples were children aged 1 years - 18 years with HSP who came to the Pediatric Department of Dr. Sardjito hospital during January 2008-August 2016 and met the inclusion criteria. Samples were taken consecutively. We looked for the presence of predictive factors for HSP based on medical records. Bivariate analysis using chi-square test to calculate $p$ value and multivariate analysis with logistic regression were conducted.

Results. A total of 80 patients were included in the study. Their followed during six month after onset. There were 31 patients $(38,75 \%)$ with nephritis. Bivariate and multivariate analysis showed that only severe abdominal symptom as a predictive factors for nephritis. ( $p$ value $=0,027$ and $p$ value $=0,021$, RR 3,759 95\% CI 1,222-11,562).

Conclusion. Severe abdominal symptom as a predictive factors for HSPN and it increase risk 3,7 times develop HSPN. Age $\geq 10$ years at onset, persistent purpura and relapse were not affect HSPN. Sari Pediatri 2016;18(3):209-13

Keywords: Henoch-Schonlein purpura, predictive factors, nephritis, severe abdominal symptom, persistent purpura

Alamat korespondensi: Dr. Ahmad Wisnu Wardhana. Bagian Ilmu Kesehatan Anak Fakultas Kedokteran Universitas Gadjah Mada/RSUP Dr. Sardjito, Yogyakarta. Email: wisnwwardhana999@gmail.com 
$\mathrm{P}$ urpura Henoch-Schonlein (PHS) merupakan salah satu penyebab tersering vaskulitis sistemik pada anak usia 3-10 tahun. Etiologi belum diketahui secara pasti. Diagnosis berdasarkan temuan purpura palpable, nyeri abdomen difus, artritis/artralgia akut, keterlibatan ginjal- baik hematuria atau proteinuria- serta biopsi kulit yang menunjukan deposisi IgA predominan pada dinding pembuluh darah kulit. ${ }^{1}$

Pada sebagian besar kasus, keterlibatan ginjal bersifat ringan dan membaik dengan sendirinya. Anak nefritis PHS mempunyai risiko lebih rendah untuk terjadinya insufisiensi ginjal dibandingkan dewasa. Morbiditas rendah pada pasien yang mengalami hematuria dan proteinuria ringan saat onset. Sementara risiko lebih tinggi didapatkan pada nefritis, nefrotik, atau tanda nefritis-nefrotik. ${ }^{2}$

Beberapa peneliti mengidentifikasi faktor prognostik anak PHS menjadi nefritis dengan analisis univariat dan multivariat. Faktor independen yang berpengaruh pada nefritis adalah purpura persisten, nyeri abdomen berat, dan usia di atas 4 atau 7 atau 10 tahun. Faktor independen lain yang memengaruhi relaps adalah penurunan aktivitas faktor XIII. ${ }^{3-5}$

Faktor prediktor yang memengaruhi nefritis adalah usia lebih dari 8 tahun saat onset (OR:2,7), nyeri abdomen (OR: 2,1), rekurensi PHS (OR: 3,1). Pasien dengan dua faktor prediktor menderita nefritis $63 \%$ dan tiga faktor risiko $87 \%$ kasus. $^{6}$ Penelitian di Indonesia didapatkan hasil lebih tinggi untuk usia 1115 tahun dengan rasio Odds 3,1, dengan menganalisis usia saat onset sebagai faktor prediktor nefritis pada anak PHS. ${ }^{7}$

Tujuan penelitian ini adalah untuk menentukan usia $\geq 10$ tahun, purpura persisten, gejala abdomen berat dan relaps sebagai faktor prediktor nefritis pada anak dengan PHS.

\section{Metode}

Dilakukan penelitian kohort retrospektif pada anak dengan PHS di Instalasi Kesehatan Anak RSUP Dr. Sardjito kemudian diikuti sampai dengan 6 bulan setelah onset. Penelitian dilakukan pada bulan September 2016 dengan mengambil data rekam medis periode Januari 2008 - Agustus 2016. Kriteria inklusi adalah anak dengan gejala trias PHS atau terdiagnosis sebagai PHS yang berusia $1-18$ tahun yang dirawat di Instalasi Kesehatan Anak RSUP Dr. Sardjito Yogyakarta. Kriteria eksklusi adalah pasien sudah terdiagnosis nefritis saat onset dan data tidak lengkap.

Besar sampel penelitian dihitung dengan rumus besar sampel minimal untuk studi faktor prognostik. Besar sampel yang diperlukan 80 anak. Sampel dipilih secara consecutive sampling berdasarkan kriteria inklusi dan eksklusi. Penelusuran faktor prediktor berupa usia $\geq 10$ tahun, purpura persisten, gejala abdomen berat, dan relaps dilakukan melalui rekam medis dan dilakukan analisis secara statistik. Penelitian dilakukan setelah mendapat persetujuan dari komite etik Fakultas Kedokteran Universitas Gadjah Mada.

Analisis data dilakukan dengan menggunakan program statistik SPSS versi 23. Analisis bivariat digunakan untuk menghitung nilai $\mathrm{p}$ faktor prediktor terhadap kejadian nefritis. Variabel yang memiliki nilai $\mathrm{p}<0,25$ pada analisis bivariat kemudian dianalisis multivariat menggunakan regresi logistik.

Tabel 1. Karakteristik dasar subyek penelitian

\begin{tabular}{lc}
\hline Karakteristik & $\mathrm{n}(\%)$ \\
\hline Rata-rata usia, rentang usia (tahun) & $8,05(3-17)$ \\
Jenis kelamin & \\
Laki-laki & $36(45)$ \\
Perempuan & $44(55)$ \\
Nefritis & $31(38,8)$ \\
Tidak nefritis & $49(61,3)$ \\
Manifestasi klinis saat onset & \\
Purpura palpabel & $80(100)$ \\
Nyeri abdomen difus & $61(76,25)$ \\
Artritis/artralgia & $41(51,25)$ \\
Gejala neurologi (kejang) & $1(1,25)$ \\
Hasil laboratorium saat onset & \\
Anemia & $20(25)$ \\
Leukositosis & $32(40)$ \\
Trombositosis & $47(58,75)$ \\
Tinja berdarah & $17(21,25)$ \\
Hasil biopsi kulit positif & $22(100)$ \\
Terapi analgesik & $40(50)$ \\
Ibuprofen & $39(97,5)$ \\
Parasetamol & $1(2,5)$ \\
Terapi kortikosteroid & $80(100)$ \\
Metilprednisolon & $72(90)$ \\
Prednison & $8(10)$ \\
Terapi imunosupresif & $5(6,3)$ \\
Siklofosfamid & $4(80)$ \\
Azatiopirin & $1(20)$ \\
\hline
\end{tabular}




\section{Hasil}

Didapat 108 pasien PHS, diambil 80 pasien yang memenuhi kriteria inklusi dan telah melewati kriteria eksklusi. Rentang usia 3-17 tahun. Tidak ada perbedaan signifikan pada rasio jenis kelamin. Nefritis terjadi pada 31 pasien $(38,8 \%)$. Manifestasi klinis terbanyak selain purpura palpable adalah nyeri abdomen difus. Dari 22 pasien yang dilakukan biopsi kulit, seluruhnya mendukung diagnosis PHS. Semua pasien mendapatkan terapi kortikosteroid. Terapi imunosupresif diberikan pada 5 pasien yang menderita nefritis. Karakteristik dasar yang dinilai tertera pada Tabel 1.

Rentang waktu kejadian nefritis terbanyak adalah $\geq 7$ hari sampai 30 hari. Hematuria mikroskopik didapatkan paling banyak diikuti oleh hematuria dengan proteinuria. Manifestasi klinis nefritis tertera pada Tabel 2.

Analisis faktor prediktor nefritis dengan bivariat dan multivariat mendapatkan perbedaan bermakna, hanya pada gejala abdomen berat masing-masing dengan nilai $\mathrm{p}=0,027$ dan $\mathrm{p}=0,076$, dan $\mathrm{RR} 3,759$ (IK95\%:1,222-11,562) untuk analisis multivariat (Tabel 3).

Tabel 2. Manifestasi klinis nefritis

\begin{tabular}{lc}
\hline Manifestasi & $\mathrm{n}(\%)$ \\
\hline Rentang waktu kejadian nefritis (hari) & \\
$<7$ & $4(12,9)$ \\
$\geq 7-30$ & $15(48,39)$ \\
$>30-90$ & $10(32,26)$ \\
$>90-180$ & $2(6,45)$ \\
Hematuria mikroskopik & $28(90,32)$ \\
Hematuria makroskopik & $3(9,68)$ \\
Hematuria dengan proteinuria & $22(70,9)$ \\
Hipertensi & $2(6,45)$ \\
\hline
\end{tabular}

\section{Pembahasan}

Rentang usia pasien didapatkan 3 -17 tahun dan tidak ditemukan perbedaan yang signifikan pada jenis kelamin laki-laki: perempuan $(1: 1,2)$. PHS paling sering terjadi pada usia antara 3-15 tahun dan laki-laki sedikit lebih sering terkena dibandingkan dengan perempuan $(1,5: 1)$. Selain itu, PHS juga jarang ditemukan pada usia kurang dari 2 tahun. ${ }^{8}$ Tidak terdapat perbedaan yang signifikan antara rasio jenis kelamin laki-laki dan perempuan $(1,1: 1){ }^{9}$

Manifestasi klinis terbanyak saat onset setelah purpura palpable adalah nyeri abdomen (76,25\%). Manifestasi lain yang sering muncul pada anak lakilaki dengan PHS adalah orkitis dan pembengkakan skrotum (35\% kasus)..$^{10}$ Biopsi kulit yang dilakukan pada 22 pasien, seluruhnya memberikan gambaran histologi mendukung PHS. Sensitivitas dan spesifisitas biopsi kulit pada PHS masing-masing adalah 93\% dan 89\%. ${ }^{11}$ Indikasi dilakukan biopsi kulit hanya pada manifestasi kulit atipikal atau gejala dari penyakit yang tidak lengkap. ${ }^{12}$

Pemeriksaan darah rutin mendapatkan anemia, leukositosis, dan trombositosis masing-masing pada $25 \%$, 40\%, dan 58,7\%. Leukositosis dan trombositosis berhubungan dengan perdarahan gastrointestinal. ${ }^{13}$ Trombositosis sering ditemukan pada fase akut dan dihubungkan dengan derajat penyakit. Pada PHS didapatkan sitokin proinflamasi IL-6 menginduksi trombositosis reaktif. ${ }^{14}$

Buang air besar disertai darah merupakan manifestasi gejala abdomen berat. Pada penelitian ini ditemukan $21,25 \%$ kasus. Penyebab manifestasi ini di antaranya adalah perdarahan submukosa atau intramural, ulserasi dan intususepsi dengan atau tanpa vaskulitis intestinal dan mesenterium. Intususepsi terjadi pada $2-3 \%$ pasien dan sebagian besar pada

Tabel 3. Analisis bivariat dan multivariat faktor prediktor nefritis pada anak dengan PHS

\begin{tabular}{lccccc}
\hline Variabel & \multicolumn{2}{c}{ Bivariat } & \multicolumn{3}{c}{ Multivariat } \\
\hline & $\mathrm{n}(\%)$ & Nilai $\mathrm{p}$ & Nilai $\mathrm{p}$ & $\mathrm{RR}$ & $\mathrm{IK} 95 \%$ \\
Usia $\geq 10$ tahun & $12(52,2)$ & 0,117 & 0,076 & 2,553 & $0,908-7,179$ \\
Purpura persisten & $0(0,0)$ & 1,000 & & & \\
Gejala abdomen berat & $11(61,1)$ & $0,027^{*}$ & $0,021^{*}$ & 3,759 & $1,22-11,562$ \\
Relaps & $0(0,0)$ & 0,519 & & & \\
\hline
\end{tabular}

Keterangan: ${ }^{*}$ uji chi-square dan uji regresi logistik bermakna secara statistik jika $p<0,05$ 
ileo-ileal. ${ }^{10}$ Studi sebelumnya juga melaporkan hasil serupa. ${ }^{7,15}$

Semua pasien mendapatkan terapi kortikosteroid, yaitu metilprednisolon dan prednison. Kortikosteroid berfungsi menghambat proliferasi sel T, T-cell dependent immunity, dan transkripsi gen sitokin (IL-1,IL2 ,IL-6, interferon gamma, TNF- $\alpha$ ). ${ }^{16}$ Terdapat bukti pemberian terapi awal prednison dengan dosis 1-2 mg/ $\mathrm{kg} /$ hari selama 2 minggu menurunkan intensitas nyeri sendi dan nyeri abdomen pada anak dengan PHS. ${ }^{5}$ Pemberian terapi awal prednison juga menurunkan rata-rata waktu resolusi nyeri abdomen pada anak dengan PHS. ${ }^{17}$ Metaanalisis yang dilakukan pada lima penelitian acak terkontrol didapatkan tidak terdapat perbedaan bermakna terhadap kejadian penyakit ginjal persisten (hematuria mikroskopik, proteinuria, hipertensi, penurunan fungsi ginjal) pada pemberian prednison selama 2-4 minggu dan yang tidak diberi terapi. $^{18}$

Angka kejadian nefritis pada studi kami didapatkan pada 31 anak $(38,7 \%)$ pasien PHS. Nefritis dilaporkan terjadi pada $12-92 \%$ PHS, tetapi paling sering pada 20\%-60\% kasus PHS. Studi sebelumnya melaporkan hasil serupa, yaitu $29 \% .{ }^{19}$ Rentang waktu antara kejadian nefritis dan onset PHS terbanyak pada $\geq 7$ hari sampai dengan 30 hari. Hal tersebut serupa dengan studi sebelumnya yang melaporkan rentang $<1$ bulan (87\%). ${ }^{6}$ Interval terpanjang didapatkan pada 3 (26,6\%), 6 (31,2\%), dan 12 bulan $(35,4 \%)$ setelah onset pertama PHS. ${ }^{3}$

Manifestasi nefritis dapat berupa hematuria, proteinuria, sindrom nefrotik, sindrom nefritis, gangguan ginjal, dan hipertensi. ${ }^{20}$ Terbanyak, ditemukan hematuria mikroskopik pada 28 (90,32\%) kasus, diikuti oleh hematuria dengan proteinuria dan hematuria makroskopik. Pada kelainan glomerulus, selain hematuria juga bisa ditemukan sedimen eritrosit, eritrosit dismorfik serta proteinuria persisten dan berat $\geq 2+.{ }^{21}$ Hematuria makroskopik diduga berhubungan dengan tingginya angka kresens pada biopsi ginjal dan fungsi ginjal yang buruk. ${ }^{22}$ Rekomendasi pada pasien dengan hasil urinalisis normal atau hematuria perlu dilakukan urinalisis tiap bulan selama enam bulan untuk mendeteksi tanda keterlibatan ginjal. ${ }^{23}$

Analisis bivariat yang dilakukan untuk mengetahui faktor prediktor yang berpengaruh terhadap kejadian nefritis mendapatkan perbedaan bermakna hanya gejala abdomen berat. Hasil serupa juga didapatkan pada analisis bivariat sebelumnya. ${ }^{24}$ Analisis multivariat mendapatkan hasil bermakna pada gejala abdomen berat terhadap kejadian nefritis. Gejala abdomen berat juga meningkatkan risiko terjadinya nefritis 3,7 kali dibanding tanpa gejala abdomen berat. Gejala abdomen berat merupakan vaskulitis aktif dan ekstensif yang merupakan faktor risiko kejadian nefritis PHS. ${ }^{6} \mathrm{CD}_{4}^{+} \mathrm{CD}_{25}{ }^{+}$Treg cells berperan menjaga toleransi melalui inhibisi aktivasi dan proliferasi sel $\mathrm{T}$ autoreaktif. $\mathrm{CD}_{4}^{+} \mathrm{CD}_{25}{ }^{+}$Treg cells menurun pada pasien nefritis PHS. Percobaan pada tikus didapatkan $\mathrm{CD}_{4}^{+}$ $\mathrm{CD}_{25}{ }^{+}$Treg cells mencegah inflamasi gastrointestinal pada penyakit autoimun. ${ }^{25} \mathrm{Hal}$ tersebut sesuai dengan penelitian sebelumnya yang menyatakan gejala abdomen berat meningkatkan risiko 3,26 kali terhadap kejadian nefritis. ${ }^{3}$

Kelemahan penelitian kami adalah penggunaan desain penelitian retrospektif dan tidak dilakukan biopsi ginjal untuk penegakan nefritis PHS. Perlu dilakukan penelitian lebih lanjut secara prospektif dan biopsi ginjal untuk diagnosis definitif nefritis PHS

\section{Kesimpulan}

Gejala abdomen berat merupakan faktor prediktor pada kejadian nefritis PHS dan meningkatkan risiko 3,7 kali terhadap kejadian nefritis PHS. Usia $\geq 10$ tahun, purpura persisten, dan relaps tidak terbukti berpengaruh pada kejadian nefritis PHS.

\section{Daftar pustaka}

1. Zafanello M. Henoch-Schonlein purpura nephritis in childhood: an update of glomerulopathies clinical and treatment aspects. Sharma Prabhakar, penyunting. Diunduh tanggal 3 Oktober 2016. Didapat dari: www.intechopen.com.

2. Bogdanovic R. Henoch-Schonlein purpura nephritis in children: risk factors, prevention and treatment. Acta Paediatrica 2009;98:1882-9.

3. Kaku Y, Nohara K, Honda S. Renal involvement in HenochSchonlein purpura: a multivariate analysis of prognostic factors. Kidney Int 1998;53:1755-59.

4. Shin JJ, Park JM, Shin YH, Hwang DH, Kim JH, Lee JS. Predictive factors for nephritis, relapse and significant proteinuria in childhood Henoch-Schonlein purpura. Scand J Rheumatol 2006;35:56-60

5. Ronkainen J, Koskimies O, Ala Houhala M, Antikainen M, Merenmies J, Rajantie J, dkk. Early prednisone therapy in 
Henoch-Schonlein purpura : a randomized, double blind, placebo-controlled trial. J Pediatr 2006;149:241-7.

6. Jauhola O, Ronkainen J, Koskimies O, Ala-Houhala M, Arikoski P, Holtta T, dkk. Renal manifestations of HenochSchonlein purpura in a 6-month prospective study of 223 children. Arch Dis Child 2010;95:877-82.

7. Ghrahani R, Ledika MA, Sapartini G, Setabudiawan B. Age of onset as a risk factor of renal involvement in Henoch-Schonlein purpura. Asia Pac Allergy 2014;4:42-7.

8. Brogan P, Bagga A. Leukocytoclastic vasculitis. Dalam: Textbook of pediatric rheumatology. Edisi ke-7. Philadelphia: Elsevier; 2016.h.483-97.

9. Haghighat M, Hashemi G, Hashemi L. Henoch-Schonlein purpura in children: our experience with 165 cases from southern Iran. MJIRI 2002;16:5-8.

10. Gedalia A. Henoch-Schonlein purpura. Curr Rheumatol Rep 2004;6:195-202.

11. Ozen S, Pistorio A, Lusan SM, Bakkaloglu A, Herlin T, Brik R dkk. EULAR/PRINTO/PRES criteria for Henoch-Schonlein purpura, childhood polyarteritis nodosa, childhood wegener granulomatosis, and childhood takayasu arteritis: Ankara 2008.Part II. Final classification criteria. Ann Rheum Dis 2010;69:798-806.

12. Murgu A, Mihaila D, Cozma L, Chiforeanu AM. Indications and limitations of histopathological skin investigation of Henoch-Schonlein purpura in children. Rom J Morphol 2012;53:769-73.

13. Lin SJ, Huang JL, Hsieh KH. Clinical and laboratory correlation of acute Henoch-Schonlein purpura in children. Zhonghua Min Guo Xiao Er Ke Yi Xue Hui Zha Zhi 1998;39:94-8.

14. Elmas TA, Tabel Y. Platelet counts in children with HenochSchonlein purpura-relationship to renal involvment. J Clin Lab Anal 2016;30:71-4.
15. Chen AC, Lin CL, Shen TC, Li TC, Sung FC, Wei CC. HSP and HSP nephritis: a population based study. Pediatric Res 2016;79:559-64.

16. Kawasaki Y, Suzuki H. Henoch-Schonlein Nephritis. Dalam: Geary D, Shaefer F, penyunting. Comprehensive pediatric nephrology. Edisi ke-1. Philadelphia: Mosby Elsevier; 2008.h.343-51.

17. Weiss PF, Feinstein JA, Luan X, Burham JM, Feudtner C. Effects of corticosteroid on Henoch-Schonlein purpura: a systematic review. Pediatrics 2007;120:1079-87.

18. KDIGO. Chapter 11: Henoch-Schonlein purpura nephritis. KIS 2012;2:218-20.

19. Aalberse J, Dolman K, Ramnath G, Pereira RR, Davin JC. Henoch-Schonlein purpura in children: an epidemiological study among Dutch paediatricians on incidence and diagnostic criteria. Ann Rheum Dis 2007;66:1648-50.

20. Tizard EJ, Ayres MJ. Henoch-schonlein purpura. Arch Dis Child Ed Pract 2008;93:1-8.

21. Yap KH, Lau PY. Hematuria and proteinuria. Dalam: Comprehensive pediatric nephrology. Missouri: Mosby; 2008.h.179-93.

22. Rai A, Nast C, Adler S. Henoch-Schonlein purpura nephritis. J Am Soc Nephrol 1999;10:2367.

23. Narchi H. Risk of long term renal impairment and duration of follow up recommended for Henoch-Schonlein purpura with normal or minimal urinary findings: a systematic review. Arch Dis Child 2005;90:916-20.

24. de-Almeida JLJ, Campos LMA, Paim LB, Leone C, Koch VHK, Silva CAA. Renal involvement in Henoch-Schonlein purpura: a multivariate analysis of initial prognostic factors. J Pediatr (Rio J) 2007;83:259-66.

25. Huang H, Sun W, Liang Y, Long XD, Peng Y, Liu Z dkk. $\mathrm{CD}_{4}{ }^{+} \mathrm{CD}_{25}{ }^{+}$Treg cells in Henoch-Schonlein Purpura nephritis patients. J Aller Immuno 2014;1:008. 